\title{
Some strategic aspects of animal protein production
}

\author{
PÉTER HORN \\ Kaposvár University, Faculty of Agricultural and Environmental Sciences, \\ Department of Animal Husbandry and Management, Kaposvár, Hungary \\ horn.peter@ke.hu
}

\begin{abstract}
Summary
The access to food shaped human societies and dietary models throughout the history of mankind. Animal protein consumption became a part of human culture. Data are presented showing the relationship of daily calorie and animal protein consumption as affected by capita GDP changes. Examples are presented how genetic improvement of animal and fodder plants influenced the resource efficiency and the overall environmental footprint per unit product. The two examples presented are: the dairy industry of the USA the 1944 and 2007 situation, and the Hungarian broiler chicken sector considering data relevant to 1930, 1960 and 2010. In both cases, dramatic improvements in resource efficiency could be demonstrated. The agricultural area required to animal feed production was reduced by more than $80 \%$ in both cases per unit product. Future possibilities are briefly discussed, referring to the still unutilized land reserves of the Globe, the new evolving technologies in progress inclusive the CASPR/Cas 9 genetic editing methods.
\end{abstract}

Keywords: animal protein consumption, income, animal production environmental footprint, improvement possibilities

\section{Introduction}

The access to food shaped human societies and dietary models throughout the history of mankind.

Our closest relatives the anthropoid apes were plant eaters, typical vegetarians, able to digest fiber rich feedstuffs of plant origin. The Homo erectus, later the Homo sapiens required much more concentrated energy and protein rich diets, inclusive animal proteins.

The reasons for this were: a greatly reduced and shorter digestive tract the significantly reduced ability to digest crude fiber, reduced enzyme activity to utilize raw foodstuffs of plant or animal origin, the human brain needs $20 \%$ of all the energy consumed for its maintenance compared to $8 \%$ typical for anthropoid apes (Horn, 2015).

The Homo sapiens became an omnivorous species requiring both nutrients of plant and animal origin. Animal product protein consumption is necessary to maintain good health status, as they contain 
essential feed ingredients (amino acids, micro and macro minerals, vitamins) which are not available in food stuffs of plant origin (Murphy and Allen, 2003). It is well proven that populations deprived of proteins of high biological value during critical phases of their life will be retarded in growth and even the potential brain capacity will not be reached till the end of puberty, as many well documented surveys indicate.

Therefore it is not surprising that mostly irrespective of origin, social cultural background and even religion, when disposable income levels rise per capita consumption of foodstuffs of animal origin do increase.

It can be stated that since Homo sapiens evolved, meat consumption (and animal protein consumption) became part of human culture (Hoquette, 2016), this is true despite the fact that $1-9 \%$ of the World population depending on regions is vegetarian (Ruby, 2012).

In the followings I will discuss some aspects related to animal production, and some future trends.

Some characteristic features of animal protein consumption in the World During the last 50 years significant changes occurred in the animal production, and per capita consumption of animal products. In Table 1 the main data are summarized.

Table 1. Change of animal product consumption per capita/year in 50 years*

\begin{tabular}{lcc}
\hline & \multicolumn{2}{c}{ Consumption per person/year } \\
\cline { 2 - 3 } & $1964-1965$ & 2015 \\
\hline Milk and milk products (kg) & 74 & 83 \\
Eggs (kg) & 4.6 & 8.9 \\
Beef $(\mathrm{kg})$ & 10.0 & 10.1 \\
Pork $(\mathrm{kg})$ & 9.1 & 15.1 \\
Small ruminants $(\mathrm{kg})$ & 1.8 & 2.4 \\
Poultry $(\mathrm{kg})$ & 3.2 & 14.1 \\
Meat total $(\mathrm{kg})$ & 24.1 & 41.7 \\
World population (billion) & 3.2 & 7.4 \\
\hline
\end{tabular}

Source: *FAO (2017), ** Mottet and Tempio (2016)

The per capita consumption data are the more impressive, as the World population has increased from 3.2 billion in 1964-1965 to 7.4 billion in 2015.

Table 2 the daily calorie and protein intakes per capita are summarized as influenced by income levels. The data covering 162 countries grouped in 5 income levels. The wealthiest groups consume 1.5 times more energy per person than the poorest. Total protein consumption is twice as high in the richest group animal protein and meat protein consumption is 5 times higher in the wealthiest group compared to the poorest. 
The data indicate that among the 162 countries only 48 are sufficiently (or even over) supplied with animal proteins, considering the required cca $50 \mathrm{~g}$ day optimal level.

Table 2. Calorie and protein intake be income level

\begin{tabular}{|c|c|c|c|c|c|c|}
\hline & \multicolumn{6}{|c|}{ Income groups } \\
\hline & Low & $\begin{array}{c}\text { Lower } \\
\text { middle } \\
\text { low }\end{array}$ & $\begin{array}{l}\text { Upper } \\
\text { middle }\end{array}$ & $\begin{array}{c}\text { High } \\
\text { non } \\
\text { OECD }\end{array}$ & $\begin{array}{l}\text { High } \\
\text { OECD }\end{array}$ & World \\
\hline Number countries & 28 & 40 & 46 & 30 & 18 & 162 \\
\hline Population (billion) & 0,7 & 2,3 & 2,2 & 0,6 & 1,0 & 6,9 \\
\hline GDP (USD) & 566 & 2.025 & 6.685 & 26.919 & 41.190 & 9.430 \\
\hline Urban population (\%) & 30 & 45 & 61 & 69 & 78 & 52 \\
\hline $\begin{array}{l}\text { Total energy } \\
\text { (kcal/person/day) }\end{array}$ & 2.287 & 2.597 & 2.896 & 2.987 & 3.363 & 2.847 \\
\hline $\begin{array}{l}\text { Total protein intake per } \\
\text { person/day }\end{array}$ & 58 & 69 & 82 & 94 & 104 & 80 \\
\hline $\begin{array}{l}\text { Animal protein per } \\
\text { person/day }\end{array}$ & 13 & 24 & 37 & 59 & 62 & 32 \\
\hline $\begin{array}{l}\text { Meat protein per } \\
\text { person/day }\end{array}$ & 6 & 12 & 19 & 30 & 30 & 15 \\
\hline
\end{tabular}

Source: Sans and Combris (2015)

The forecasts indicate a significant further growth of animal product output, as probably incomes per capita will increase in the future, a better animal protein supply in needed for the majority of the World population to improve their health status and overall wellbeing.

In Table 3 the meat production increases per annum in \% between 1960-2010, and the forecasted increase till 2050 are summarised considering the different animal production sectors. Egg production in expected to grow by over $60 \%$. Milk production should increase by over 200\% (Tarawali et al., 2011. cit. Horn, 2013)

Table 3. Meat production increases per annum (\%) between 1960-2010 and forecasted increase till $2050(2005=100 \%)$

\begin{tabular}{lcc}
\hline & $\begin{array}{c}\text { Annual increase (\%) } \\
(1960-2010)\end{array}$ & $\begin{array}{c}\text { Expected increase till 2050 } \\
\text { (basis 2005=100\%) }\end{array}$ \\
\hline Poultry & 5.0 & 121 \\
Pork & 3.1 & 43 \\
Beef & 1.5 & 66 \\
Small ruminants & 1.7 & 92 \\
\hline
\end{tabular}

Source: Mottet and Tempio (2016) 
Utilization of various resources, and environmental footprint as affected by productivity of animal populations

In Table 4 the total feed producing area required for the various animal production sectors are presented.

Table 4. Feed producing area required for the various animal production sectors (million ha)

\begin{tabular}{lcccrrrr}
\hline & $\begin{array}{c}\text { Low } \\
\text { quality } \\
\text { pastures }\end{array}$ & $\begin{array}{c}\text { High } \\
\text { quality } \\
\text { pastures }\end{array}$ & Silage & Cereals & Oil seeds & Others & Total \\
& 500.6 & 547.1 & 59.4 & 73.1 & 61.5 & 125.1 & 1367.0 \\
Cattle & 782.5 & 160.4 & 9.5 & 1.6 & 2.9 & 19.5 & 976.3 \\
Small ruminants & - & - & - & 92.5 & 16.4 & 2.5 & 111.4 \\
Poultry & - & - & - & 44.8 & 2.7 & 9.3 & 56.8 \\
Pigs & 1283.1 & 707.5 & 69.8 & 212.1 & 83.5 & 156.4 & 2511.5 \\
Total & & & & & & &
\end{tabular}

Cattle (milk and beef) utilize cca. 1 billion ha of pastures and 300 million ha of all kinds of crops, in total 1367 million ha of land, which is approximately $50 \%$ of the total agricultural utilizable area of the Globe.

Small ruminants require close to 1 billion ha of mostly poor quality pastures. Most of the land grazed by ruminants would be unsuitable for cropping. It is surprizing that poultry and pig production to be supplied by feedstuffs requires less than $10 \%$ of the available agricultural area of the World, used to feed animals despite the fact that their contribution to the total animal protein supply of the 7.4 billion population is exceeding those of the other species. Regarding the word production: poultry meat is close to 110 million tons, pork is exceeding 100 million tons, eggs 70 million tons, whereas beef and small ruminant meat combined does not reach 90 million tons. In relative terms in the period 2014-2016, poultry meat represented $35 \%$, pork $37 \%$, beef $23 \%$ and sheep meat $5 \%$ of the world's meat production (Popp et al., 2017).

The data clearly indicate that the ruminant sector mostly beef cattle and small ruminants is largely dependent on more extensive type of production closely relying on the surrounding environmental conditions in the broadest sense. There is much less scope for intensification. The animal feed sources utilized are however not directly utilizable (grass, roughages) by humans.

The large improvements of genetic potential of animals in the case of which feeding and production environment could be controlled (dairy cattle, pigs, poultry) and the fodder plant yields per unit area could be greatly improved the situation changed profoundly in the last 50-60 years. 
A typical example to demonstrate this is presented on Table 5-6 showing the significant changes related to the USA dairy sector.

The data in Table 5 demonstrates the greatly increased milk yield of cows from $2074 \mathrm{~kg}$ to $9193 \mathrm{~kg}$ between 1944 and 2007, and some typical changes characterizing the dairy industry. The resource input and environment impact changes per 1 billion $\mathrm{kg}$ milk produced show drastic reductions in population sizes, nutrition resources, waste outputs and gas emissions.

Table 5. Characteristics of the 1944 and 2007 dairy production systems of the USA

\begin{tabular}{|c|c|c|}
\hline Variable & 1944 & 2007 \\
\hline Breed & $\begin{array}{l}54 \% \text { jersey, guernsey, ayrshire } \\
\text { (small breeds) } \\
46 \% \text { holstein, brown swiss } \\
\text { (large breeds) }\end{array}$ & 90 holstein \\
\hline Milk yield per cow kg day ${ }^{-1}$ & 2074 & 9193 \\
\hline Milk fat content $\%$ & $\begin{array}{l}4.20 \text { small breeds } \\
3.60 \text { large breeds }\end{array}$ & 3.69 \\
\hline Milk protein content $\%$ & $\begin{array}{l}3.50 \text { small breeds } \\
3.20 \text { large breeds }\end{array}$ & 3.05 \\
\hline Heifer cow ratio & 0.89 & 0.83 \\
\hline Heifer growth rate $\mathrm{kg} \mathrm{day}^{-1}$ & $\begin{array}{l}0.42 \text { small breeds } \\
0.59 \text { large breeds }\end{array}$ & 0.68 \\
\hline Age at first calving, mo & 27.0 & 25.5 \\
\hline Breeding method & 100 natural service & $\begin{array}{c}70 \% \text { artificid insemination } \\
30 \% \text { natural service }\end{array}$ \\
\hline Bull cow ratio & $1: 25$ & 1.83 \\
\hline Principal forage sources & pasture, hay & corn silage, alfalfa silage \\
\hline Diet type & forage+concentrate & total mixed rations \\
\hline
\end{tabular}

Approximately overall efficiency of milk production increased by over $400 \%$ during the 1944-2007 period. Based on the dataset of Capper et al. (2009) calculations showed that if it would be necessary to produce milk supplying the present needs of the USA 84 billion $\mathrm{kg}$ per annum using the 1944 breeds and feeding, 144 million ha of agricultural area would be required. The same quantity of milk can be produced applying the system typical for 2007, only on 13.6 million ha of land (Horn, 2013).

Very similar results were obtained in comparisons regarding broiler chicken production under Hungarian conditions, comparing production systems typical for the years 1930, 1960 and 2010. A broiler chicken of 1930 gained $7 \mathrm{~g}$ live weight/day, in $196023 \mathrm{~g}$, in $201058 \mathrm{~g}$. Main feed grains yielded (wheat, corn) 1.4-1.5 tha in 1930 1.9-2.6 tha in 1960, and 5.1-6.1 $\mathrm{t}$ ha in 2010. Considering all other parameters to produce the 340 000 tons of broiler meat relevant for 2013, using 1930 type broilers and cropping system 740000 ha of land would be required, in 2010 only 99 
000 ha of land is needed to produce the same broiler quantity (Horn, 2017).

Genetic improvements of animal populations and plants combined with improved overall management has led to dramatically reduced resource inputs and reduced environmental footprints per unit product (meat, eggs, milk) produced. The land area requirement as a consequence diminished in a dramatic manner.

Table 6. Comparison of resource inputs, waste output, and environmental impact of dairy production systems in 1944 and 2007

\begin{tabular}{|c|c|c|}
\hline & 1944 & 2007 \\
\hline & \multicolumn{2}{|c|}{$\begin{array}{l}\text { Resources/waste per billion } \mathrm{kg} \\
\text { milk produced }\end{array}$} \\
\hline \multicolumn{3}{|l|}{ Animals } \\
\hline Lactating cows $\times 10^{3}$ & 414.8 & 93.6 \\
\hline Dry cows $\times 10^{3}$ & 67.4 & 15.2 \\
\hline Heifers $\times 10^{3}$ & 429.2 & 90.3 \\
\hline Mature bulls $\times 10^{3}$ & 19.29 & 1.31 \\
\hline Adolescent bulls $\times 10^{3}$ & 17.17 & 1.08 \\
\hline Total population $\times 10^{3}$ & 948 & 202 \\
\hline \multicolumn{3}{|l|}{ Nutrition resources } \\
\hline Maintenance requirement $\mathrm{MJ} \times 10^{9}$ & 16.66 & 3.87 \\
\hline Maintenance protein requirement $\mathrm{kg} \times 10^{6}$ & 165.4 & 48.4 \\
\hline Feedstuffs $\mathrm{kg}$ of fresh weight $\times 10^{9}$ & 8.26 & 1.88 \\
\hline Land ha $\times 10^{3}$ & 1705 & 162 \\
\hline Water $\mathrm{L} \times 10^{9}$ & 10.76 & 3.79 \\
\hline \multicolumn{3}{|l|}{ Waste output } \\
\hline Nitrogen excretion $\mathrm{kg} \times 10^{6}$ & 17.47 & 7.91 \\
\hline Phosphors excretion $\mathrm{kg} \times 10^{6}$ & 11.21 & 3.31 \\
\hline Manure fresh weight $\mathrm{kg} \times 10^{3}$ & 7.86 & 1.91 \\
\hline \multicolumn{3}{|l|}{ Gas emissions } \\
\hline${ }^{*}$ Methane $\mathrm{kg} \times 10^{6}$ & 61.8 & 26.8 \\
\hline$* *$ Nitrous oxide $\mathrm{kg} \times 10^{3}$ & 412 & 230 \\
\hline${ }^{* * *}$ Carbon footprint $\mathrm{kg}$ of $\mathrm{CO}_{2} \times 10^{3}$ & 3.66 & 1.35 \\
\hline
\end{tabular}

Note: ${ }^{*}$ includes $\mathrm{CH}_{4}$ emissions from enteric fermentation and manure, ${ }^{* *}$ includes $\mathrm{N}_{2} \mathrm{O}$ emissions from manure and from inorganic fertilizer application (2007 only), *** includes $\mathrm{CO}_{2}$ emissions from animals, plus $\mathrm{CO}_{2}$ equivalents from $\mathrm{CH}_{4}$ and $\mathrm{N}_{2} \mathrm{O}$, Source: Capper et al. (2009)

Some future possibilities and conclusions

The Davos World Summit ranked as top priority to reduce the risks of food supply of the world's population (Radev, 2016). The possibilities are manifold. I will list only some of them. There are still uncultivated good quality land areas suitable for cropping. In Brazil 200, in India 100, in Ukraine 80, in America and Africa 50-50 million ha (Kapronczai, 2016).

Further improvement of productivity concomitant with sustainability in plant and animal agriculture is possible via knowledge and precision 
based production systems. Further improved and more sophisticated environmentally controlled animal production systems mainly/poultry, pork and milk production (Horn, 2013), are under construction worldwide. In most animal species further genetic gains are possible considering the existing genetic variance. One recent example is a new large scale broiler operation applying a new multy tier rearing system in which they were capable to grow broilers to $2.5 \mathrm{~kg}$ slaughter weight with a feed conversion of $1.08 \mathrm{~kg}$ feed per $1 \mathrm{~kg}$ liveweight gain (Van Doorn, 2018), or laying hens producing more than 420 eggs in one cycle (Sütó et al., 2018).

The new revolutionary methods developed recently to modify the genome by the CRISPR/Cas 9 will enable breeders to accelerate both genetic improvement of animals and plants (Hiripi and Gocza, 2017).

Large sample surveys published in the USA showed that even the "older type" genetically modified feed crops (soya, mays) fed to animals did not show any harmful effects, and were safe to feed (Table 7).

Table 7. Estimated cumulative number of livestock raised in the United States during the period from 2000 to 2011

\begin{tabular}{lcc}
\hline \multicolumn{1}{c}{ Industry* } & Number of livestock & $\begin{array}{c}\text { Organic livestock numbers as } \\
\text { percentage of the U. S. total }^{* *}\end{array}$ \\
\hline Broilers & $94,683,600,000$ & $0,33 \%$ \\
Layer Hens & $3,722,708,000$ & $1,97 \%$ \\
Turkeys & $2,733,500,000$ & $0,20 \%$ \\
Beef cattle & $339,350,000$ & $0,34 \%$ \\
Dairy Cows & $33,550,000$ & $2,78 \%$ \\
Hogs & $1,219,460,000$ & $0,00 \%$ \\
\hline Total & $102,732,168,000$ &
\end{tabular}

Note: * Numbers for broilers, hogs (barrows and gilts), and beef cattle (steers) are for slaughtered animals during calendar year. Dairy animals are number of dairy cows in a calendar year divided by 3 to account for 3 lactations per animal. ** USDA Economic Research Service (2013), Source: Van Eenennaam and Young (2014)

Up to the present time animal agriculture was capable to feed the growing world population covering demand at constantly higher levels throughout the last 60 years without the systematic application of GMO technologies in selection programs.

In the future it can be forecasted that with the help of CRISPR/Cas 9 technologies new genetic progress will be achieved worldwide helping to develop more efficient animal populations, serving mankind in many innovative new ways not only as producers of animal foods, as eggs, meat and milk and further processed products derived from them. 


\section{Acknowledgement}

The work is supported by the EFOP-3.6.3-VE-KOP-16-2017-0008 project is co-financed by the European Union and European Social Fund.

\section{References}

Capper, J. L.-Cady, R. Al.-Bauman, D. E. (2009): The environmental impact of dairy production 1944. compared with 2007. J. Anim. Sci. 87: 2160-2167.

FAO (2017): FAO Corp.Doc.Rep. World Agriculture: Towards 2015/2030. http:// fao.org.docrep/005/y4252e/y4252e056.htm

Hiripi L.-Gócza E. (2017): A genomszerkesztés eredményei állati kísérleti rendszerekben. [In: Balázs E.-Dudits D. (szerk.) Precíziós nemesítés.] Agroinform. Budapest. 159-170.

Hocquette, J. F. (2016): Is in vitro meat solution for the future? Meat Science. 20: 167-176.

Horn P. (2013): Korunk fó fejlődési tendenciái az élelmiszertermelésben, különös tekintettel az állattenyésztésre. Gazdálkodás. 57: 516-531.

Horn P. (2013): A tej és marhahústermelés versenyhelyzete a világ állattenyésztésében. Állattenyésztés és Takarmányozás. 62: 308-323.

Horn P. (2015): Milyen jövő vár az állattenyésztésre. Magyar Mezőgazdaság. 70. 1: 28-31.

Horn P. (2017): Az újkori állatnemesítés kialakulása. [In: Balázs E.-Dudits D. (szerk.) Precíziós nemesítés.] Agroinform. Budapest. 33-40.

Horn P.-Stefler J. (2017): A világ állati fehérjeellátása, annak humán egészségügyi szerepe, figyelemmel a húsmarha tenyésztésre. Állattenyésztés és Takarmányozás. 66. 4: 261-275.

Kapronczai I. (2016): A magyar agrárgazdaság helyzete napjainkban - kockázatok és lehetőségek. Gazdálkodás. 60. 5: 369-426.

Marton Cs. (2017): Mutáció eredetú versenyképes növényfajták és hibridek. [In: Balázs E.-Dudits D. (szerk.) Precíziós nemesítés.] Agroinform. Budapest. 5561.

Mottet, A.-Tempio, G.(2016): Global poultry production current state and future outlook and challenges. Proc. XXV. Worlds Poultry Congr. Inv. Lecture Papers. Beijing. 271-277.

Murphy, S. P.-Allen, L. H. (2003): Nutritional importance of animal source foods. J. Nutrition. 133: 3932-3935.

Popp J.-Oláh J.-Szederák J.-Harangi-Rákos M. (2017): A marhahús eloállítás nemzetközi és hazai piaci kilátásai. Állattenyésztés és Takarmányozás. 66. 4: 276-299.

Radev A. (2016): Globális kihívások az agrárszektorban. OTP Agrárkonferencia. 2016. május 16. Budapest.

Ruby, M. (2012) Vegetarianism. A blossoming field of study. Appetite. 58: 141150. 
Sans P.-Combris P. (2015): World meat consumption patterns: An overview of the last fifty years (1961-2011). Meat Sci. 109: 106-111.

Sütő, Z.-Budai, Z.-Almási, A.-Milisits, G.-Újváriné, J.-Garamvölgyi, É.-Horn, P. (2018): The effect of different housing systems on traits of experimental crossbred leghorn and brown type layers until 96 weeks of age. Hungarian Agricultural Research. 1: 15-19.

Van Doorn, D. (2018): Feed conversion 1.0 is the future. Poultry World: 2018. 3: $11-12$.

Van Eenennaam, A. L.-Young, A. E. (2014): Prevalence and impacts of genetically engineered feedstuffs on livestock populations. Journal of Animal Sci. 92: $4255-4278$. 